\title{
Pesquisa de Campo em Análise do Discurso: construindo um dispositivo de aproximação aos sentidos do trabalho no cotidiano escolar
}

Field Research on Discourse AnALysis: Discussing a Dispositive to APPROACH ON MEANINGS OF WORK IN THE EVERYDAY LIFE IN SCHOOL

\section{Bruno DEUSDARÁ*}

Resumo: Este artigo tem por objetivo problematizar as opções metodológicas em uma pesquisa de campo, a partir dos referenciais dos estudos do discurso. Parte-se de uma experiência de pesquisa de campo na sala de professores de uma escola da rede pública do Rio de Janeiro. $\mathrm{Na}$ discussão sobre as opções metodológicas, privilegiaram-se os conceitos de compreensão responsiva ativa (BAKHTIN, 2000) e de gêneros do discurso (BAKHTIN, 2000; MAINGUENEAU, 2001). Como resultado, observa-se a produtividade desses conceitos na afirmação de uma abordagem institucional das práticas de linguagem.

Palavras-chave: Trabalho docente. Análise do discurso. Gêneros do discurso. Quadro mural.

Abstract: This article aims to discuss the methodological choices in field research, from discourse studies. We analyze an experience of field research in the staff room of a public school in Rio de Janeiro. In discussing the methodological choices, preference was given to the concepts of active responsive understanding (BAKHTIN, 2000) and speech genres (BAKHTIN, 2000; MAINGUENEAU, 2001). As a result, we observe the productivity of these concepts in an institutional viewpoint of language practices.

\footnotetext{
* Doutor em Psicologia Social pela Universidade do Estado do Rio de Janeiro (2011). Mestre em Letras, área de concentração em Linguística, pela UERJ (2006). Professor Adjunto de Linguística (Instituto de Letras/UERJ) e de Língua Portuguesa e Literatura Brasileira (Instituto de Aplicação Fernando Rodrigues da Silveira/UERJ). Contato: brunodeusdara@gmail.com.
} 
Key-words: Teachers work. Discourse analysis. Discoursive genre. Notice board.

\section{Considerações Iniciais}

O debate em torno dos encaminhamentos metodológicos em análise do discurso $(\mathrm{AD})$ é, sem dúvida, tema que merece atenção relativa não apenas ao próprio desenvolvimento da investigação em tela, mas também ao potencial de reflexão teórica, de natureza interdisciplinar. Nessa direção, o presente artigo se propõe a discutir os referenciais teóricos que sustentam a opção por uma pesquisa de campo em $\mathrm{AD}$, cujo foco reside em explicitar os modos de produção de imagens discursivas do trabalho do professor, em seu cotidiano profissional.

Se digo acima que há um potencial de reflexão implicado nas opções metodológicas de uma pesquisa em $\mathrm{AD}$, tal afirmação se justifica, entre outros aspectos, pelo próprio percurso histórico de constituição do campo de estudos do discurso, cuja emergência se deu em ruptura com a análise de textos, de inspiração conteudista. Em outros trabalhos ${ }^{1}$, já se destacaram as premissas contra as quais uma perspectiva discursiva veio se insurgir, em seus primeiros gestos teóricos, nos anos sessenta do século passado.

Reivindicando a tradição hermenêutica do século XVII, as iniciativas de pesquisa em análise de conteúdo pretenderam conferir a sua prática de interpretação um rigor metodológico, que seria perseguido como possibilidade de alcançar com maior grau de precisão seus resultados. Desse modo, sua proposta residia em aliar uma tradição interpretativa a uma prática investigativa submetida aos imperativos de imparcialidade e objetividade, pilares das ciências na modernidade.

Com efeito, a aliança entre tradição hermenêutica e prática investigativa manteve grande parte dos pressupostos que remetem ao senso comum acerca da interação verbal. Pautando-se em um esquema linear, concebem-se os participantes da interação dividindo-os entre um polo ativo - o do emissor - e um polo passivo - o do receptor -, cujo pacto estabelecido entre as partes se motivaria por fazer chegar ao destinatário o máximo de informação emitida pelo remetente.

\footnotetext{
${ }^{1}$ A esse repeito, remeto o leitor a Possenti (2004) e Rocha e Deusdará $(2005,2006)$.
} 
De acordo com esse esquema, o emissor escolhe o que deseja comunicar ao receptor e o faz por meio de um texto, concebido como superfície material que carrega e, ao mesmo tempo, oculta os conteúdos transmitidos. Os equívocos, as não coincidências, os dizeres de outro modo - temas que servirão de inspiração teórica para a perspectiva discursiva assumem contornos negativos, considerados desvios da atividade de decodificação, passíveis de serem evitados.

A esse respeito, já destacamos em outro trabalho o projeto da Análise do Conteúdo (AC) de afirmar a possibilidade de "ultrapassar as 'aparências', os níveis mais superficiais do texto, residindo nesse processo de descoberta a desconfiança em relação aos planos subjetivo e ideológico, considerados elementos de deturpação da técnica" (ROCHA; DEUSDARÁ, 2005, p. 309-310).

Outro efeito desse achatamento do quadro das trocas verbais se observa em uma desqualificação do que, no esquema linear, é a suposta instância de "recepção". A ela caberia tão somente extrair os conteúdos depositados no texto no momento de sua emissão. O que acreditava então é que, se a dita leitura comum estaria suscetível aos supostos "enganos", a atividade científica deveria construir roteiros prévios, optando preferencialmente por levantamentos quantitativos, de modo que se pudessem afastar traços marcadamente pessoais em sua esperada decodificação. A neutralização das supostas impressões pessoais do pesquisador em sua atividade de investigação configura-se como objetivo a ser perseguido, cuja recompensa seria marca da confiabilidade dos resultados atingidos.

Não se pode deixar de observar que o rigor metodológico atua, pondo em ação diversas estratégias que teriam como alvo a neutralização das interferências do pesquisador nos resultados da análise. A esse respeito, é importante compreender essa neutralização como um efeito de engrenagens em ação:

... os mecanismos de funcionamento de uma pesquisa em Análise de Conteúdo encenam uma busca ou descoberta dos resultados, e não a construção de uma análise, que se depreende da não-problematização da pergunta norteadora do inquérito ao ideal de rigor metodológico pretensamente atingido por intermédio das estratégias de apagamento da presença do pesquisador. (ROCHA; DEUSDARÁ, 2005, p. 312313). 
A partir de tal perspectiva, as observações anteriores pretenderam evitar que se tomasse como natural a meta de apagamento do pesquisador frente ao próprio processo de pesquisa. Trata-se de um funcionamento que põe em jogo desde roteiros estruturados das etapas de investigação até o tratamento quantitativo dos "dados" coletados e que se sustenta em referências conceituais pouco explícitas ou mesmo insuficientemente problematizadas. Dessa forma, ressalta-se que “o rigor metodológico em análise de conteúdo e as estratégias de apagamento das implicações do pesquisador na construção de suas análises são acompanhados de uma não-explicitação da trajetória teórica" (ROCHA; DEUSDARÁ, 2005, p. 314).

O destaque conferido acima ao lugar do debate metodológico em AC permite vislumbrar alguns aspectos incompatíveis com a opção por uma abordagem discursiva das práticas de linguagem. A concepção linear das trocas verbais e as demais noções decorrentes dela já comporiam um quadro de insuficiências necessárias que apontam a impossibilidade de deslocar o debate metodológico da explicitação dos referenciais subjacentes aos seus encaminhamentos.

Motivado por esse tipo de reflexão, o presente artigo pretende oferecer contribuição que se pauta por conceitos de base da perspectiva dialógica de M. Bakhtin, fundamentando as opções metodológicas em uma pesquisa de campo $^{2}$, realizada anteriormente à qual retorno, recuperando as opções assumidas e procurando avançar na discussão teórica então mobilizada. Centro a argumentação aqui apresentada em torno da noção de compreensão responsiva ativa, como pista fundamental para uma concepção dialógica da interação verbal, que permite abordar os textos como parte material de um funcionamento institucional. Em seguida, explicito uma definição de gêneros do discurso como conceito operatório em torno dos sentidos produzidos sobre o trabalho docente no mural da sala de professores de uma escola da rede pública estadual do Rio de Janeiro. Por fim, ressalto as contribuições que essas noções oferecem para o desenvolvimento de pesquisas de campo, a partir da perspectiva discursiva, especialmente daquela que vem sendo desdobrada a partir da obra de D. Maingueneau.

\footnotetext{
${ }^{2}$ Remeto o leitor a Deusdará (2006).
} 


\section{Desnaturalizando o Funcionamento do Cotidiano do Trabalho Docente}

Neste item, centro a discussão em torno de encaminhamentos metodológicos quando o desafio que se apresenta ao pesquisador é construir um dispositivo de acesso às interações de que o professor participa em seu cotidiano de trabalho. Para isso, é preciso assumir uma concepção de cotidiano que se afasta da ilusória naturalidade, preconizada pelos manuais de metodologia.

Considerar o cotidiano como uma invenção significa reconhecer no espaço sua espessura histórica, optando por desnaturalizar a circulação dos corpos e dos textos como evidências visíveis e recorrendo à sua análise pela problematização das forças em jogo. Parece-me útil retomar a distinção proposta por Certeau entre lugar e espaço. Para ele, lugar "é a ordem (seja qual for) segundo a qual se distribuem elementos nas relações de coexistência", que se define por "uma configuração instantânea de posições" (CERTEAU, 2003, p. 201). Definido dessa maneira, o lugar supõe estabilidade, ainda que momentânea. Já o espaço "é o efeito produzido pelas operações que o orientam, o circunstanciam, o temporalizam e o levam a funcionar em unidade polivalente de programas conflituais ou proximidades contratuais" (CERTEAU, 2003, p. 202).

O espaço, portanto, não é prévio a seus usos. As dimensões físicas de um lugar, a organização dos objetos, a distribuição dos corpos fazem ver formas que, quando interrogadas a partir dos gestos que as sustentam, das práticas que as conformam, permitem acessar as apropriações do espaço, como um campo de forças em funcionamento, cujas formas são sempre arranjos provisórios. O tipo de conhecimento possível no investimento em uma análise do espaço é circunstancial e não almeja a verdades universalmente aceitas.

Na pesquisa em questão, partiu-se de uma queixa recorrente entre os profissionais de educação acerca de sua sobrecarregada jornada de tarefas. O alvo desse tipo de reclamação é um conjunto diversificado e bastante heterogêneo de solicitações que se configuram como expectativas em torno de sua atividade profissional. A aposta residia em poder percorrer essas reclamações como indicadores de forças em jogo na produção de um cotidiano sentido como produtor de fadiga e adoecimento. 
Tratando esse tipo de reclamação como demanda de pesquisa, elaborou-se como objetivo a ser perseguido a explicitação dos modos a partir dos quais imagens discursivas de trabalho docente se produzem no cotidiano escolar, para além da clássica interação entre professor e aluno, na sala de aula. Ao percorrer a produção de imagens discursivas, o que se interroga é o funcionamento institucional por meio do qual certos traços se tornam visíveis, ganham forma, em detrimento de outros.

Sem me ser possível explorar mais detidamente o tipo de reflexão que sustenta a opção a seguir, anunciarei que, para as observações realizadas na pesquisa de campo, elegeu-se a sala de professores como espaço-tempo privilegiado. Apenas para não deixar de indicar o que me parece uma justificativa importante, a sala de professores é concebida como espaço onde, ao menos aparentemente, os profissionais estariam descansando. No entanto, a experiência coletiva nesse espaço autoriza supor que haja conversas a respeito de situações cotidianas, combinados de condutas em relação a certos alunos ou turmas, solicitações de agendamento de reunião, explicitação de dúvidas, entre outras interações, evidenciando que naquele espaço o professor também é convocado ao trabalho.

A partir dos questionamentos delineados anteriormente, interessa-me iniciar a discussão central deste item, abordando a invenção de um dispositivo de acesso às interações ocorridas na sala de professores, de uma escola da rede pública do estado do Rio de Janeiro. Não resta dúvida da diversidade de caminhos que poderiam ser assumidos pelo pesquisador no período de observações: gravação das interações, elaboração de diário de campo, execução de entrevistas individuais ou de grupos focais, entre outras alternativas. No entanto, alguns embates em torno da atividade de afixar textos no quadro mural indicaram também atravessar seu projeto de informar. Quem pode afixar um texto no mural da sala de professores? Que gêneros são autorizados a figurar no mural? Que outras temáticas se julgam necessárias/importantes de serem divulgadas?

Problematizar o funcionamento do mural como mero "veículo de informações" precisa vir acompanhado de um conjunto de observações que deem conta dos modos de funcionamento do quadro de avisos: quem está autorizado a enunciar utilizando-o como mídium, a frequência de aproximação e leitura dos textos afixados pelos coenunciadores, associados a que rede de práticas discursivas se dão seus modos de funcionamento. 


\section{Usos do Mural}

No período de observação na sala de professores, chamou especial atenção o lugar atribuído ao quadro mural. Trata-se de um quadro de madeira, coberto, em toda a sua extensão, por um feltro verde, como os diversos quadros murais com os quais estamos habituados a conviver em espaços escolares, repartições públicas em geral, hospitais, escritórios, recepções.

Murais informativos fazem parte de nosso cotidiano em escolas, repartições públicas, locais de passagem. Esse objeto estático, à primeira vista, poderia ser apropriado por aqueles que imaginam ser a troca verbal uma relação linear entre um emissor, que afixaria os textos, e um receptor, que eventualmente o leria. A meu ver, tal ponto de vista merece ser colocado em discussão, observando que, quando se torna quase invisível, esse tipo de dispositivo teria atingido um grau importante de efeito de objetividade para os textos que circulam nele.

Argumentarei a esse respeito com um breve levantamento acerca dos sentidos atribuídos ao quadro mural, realizado em uma busca na página eletrônica do Google, recolhendo instruções de uso, explicações a respeito do mural, ou mesmo menções a sua utilização.

Um primeiro uso habitualmente indicado refere-se ao mural como metáfora em ambientes virtuais. Como resultado para a busca a partir de descritores como "quadro-mural", "mural", "o que é mural", os resultados encaminhavam a algumas centenas de páginas. $\mathrm{Na}$ maior parte das ocorrências, tratava-se da referência aos murais constantes em páginas eletrônicas. Tais murais são utilizados como espaço de diálogo entre os usuários e o provedor da página. Neles são "afixadas" perguntas com as dúvidas de seus usuários, seguidas das respostas dadas pelo provedor. Algumas chegam mesmo a pôr em cena um espaço delimitado com moldura, de fundo verde (simulando a cobertura habitual de feltro desse tipo de "recurso") ou marrom (aproximando-se dos modelos compostos por cortiça).

Nesses exemplos, o mural encena um diálogo entre indivíduos (é possível também que a pessoa responsável pela manutenção da página eletrônica fale não em nome próprio, mas como representante de uma empresa ou entidade), cuja divulgação é pública. Ou seja, qualquer um que tenha dúvidas, reclamações, ou questões de outra ordem a colocar terá acesso 
às trocas de mensagens anteriores. Tal interação pressupõe coenunciadores em situações de enunciação distintas.

Além de pôr em cena um dado funcionamento supostamente democrático da página, já que, nessas seções, pode-se ter acesso aos elogios, mas também às críticas, o fato de o diálogo entre os coenunciadores poder ser visto por outros usuários da página produz sentidos relativos à aparente transparência de suas ações. O espaço democrático garantido e a transparência de suas ações contam com o usuário da página, mesmo que sem lançar mão de tais recursos, como testemunha. Percebe-se assim uma importante estratégia do mural, ao mesmo tempo em que se legitima como espaço democrático e afeito à transparência, assegura o leitor como sua testemunha. Esse sentido não se inscreve como conteúdo, mas se produz a partir do modo como os textos circulam nesse ambiente.

Outro uso a que se faz menção, na busca virtual realizada, aponta o mural como "recurso" institucional para a aprendizagem. Como resultado, encontraram-se alguns manuais que se propõem a prescrever a utilização do quadro mural como "recurso" pedagógico. Entre eles, havia um proveniente de uma instituição militar. No referido manual, o mural é compreendido como um "recurso" de comunicação entre "instrutor-instruendo". Cabe ao instrutor sua utilização, associando a ele diferentes recursos visuais e materiais com uma finalidade determinada: "motivar os instruendos".

Nesse manual, o mural se define da seguinte maneira:

Os quadros murais são um valioso recurso para auxiliar o processo ensino-aprendizagem, uma vez que facilitam a comunicação instrutor-instruendos e contribuem para motivar os instruendos. Podem ser fixos ou móveis ou então afixados em quadros ou em cavaletes específicos. ${ }^{3}$

O mural, como recurso pedagógico em instituições militares, tem um projeto bem definido: acessório de comunicação do instrutor, tem como

${ }^{3}$ Fonte: <http://www.easa.eb.mil.br/paginas/manual_instrutor/cap_5.html>. Acesso em: 18 jun. 2006. A página não está mais ativa, mas o manual pode ser encontrado em: <http://pt.scribd.com/doc/72084814/T-21-250-Manual-DoInstrutor>. 
finalidade gerar um conjunto de motivações no instruendo. Para atingir tal finalidade, o manual prescreve procedimentos básicos de utilização do mural:

(1) Preparar um esboço prévio, atentando para a disposição do que conterá o quadro mural;

(2) Usar letreiros nítidos que permitam a leitura sem esforço;

(3) Utilizar ilustrações atraentes;

(4) Utilizar recursos como barbante, fitas, setas e linhas coloridas para caracterizar a idéia de fluxo ou seqüência, quando for o caso;

(5) Manter o quadro mural atualizado;

(6) Utilizar legendas simples e objetivas;

(7) Fixar o quadro mural a uma altura conveniente, para que todos os instruendos possam ver; e

(8) Dar tempo suficiente para que possa ser lido.

O breve levantamento anterior já inspira a compreender esse projeto de informar dos murais como um dos efeitos decorrentes de suas apropriações. Tal levantamento é aqui exposto para contribuir com uma análise que não separe os textos de seus modos de circulação.

Eis enfim o que se pretende sustentar como opção metodológica: 0 mural como dispositivo de acesso a uma dada massa de textos. Seguir com o esforço de desnaturalizar o mural é retirá-lo do lugar convencionalmente atribuído - o de um mero veículo de informações. Trata-se de observar que escolhas é preciso fazer para pensá-lo como um dispositivo de acesso a enunciações anteriores e a certos pressupostos sobre o trabalho docente que têm na sala de professores seu contexto privilegiado de produção/circulação de textos.

Para isso, é necessário considerar que, quando alguém afixa algo no mural, de algum modo dialoga com certos pressupostos acerca do trabalho docente. Como exemplo, diria que, quando alguém afixa um texto sobre gravidez na adolescência, deve-se supor que, de algum modo, os profissionais que circulam por aquele espaço - ou seja, os professores da escola - estariam implicados com esse tema. Em se tratando de uma escola de Ensino Médio, cujo corpo discente é formado basicamente de adolescentes, provavelmente tal texto não pretende que os professores estejam apenas "informados", mas que desenvolvam algum grau de compromisso com o tema, levando-o para a sala de aula. 
Esse tipo de consideração só é possível quando se abandona a ideia de que o texto carregaria uma significação oculta, estável desde o momento de sua produção. A perspectiva dialógica aqui reivindicada assume o texto como parte material de uma situação de troca, em que enunciador só pode tomar a palavra, porque, ao fazê-lo, constrói uma imagem daquele a quem ele se dirige. A compreensão de um texto passa por uma tentativa de reconstrução dessa imagem (sem que se possa atingi-la), a partir das pistas oferecidas pelo enunciado, e de hipóteses sobre o posicionamento esperado.

No próximo item, será possível demonstrar, a partir da indicação da ocorrência de textos afixados no mural, no período da pesquisa de campo, a argumentação que estou sustentando aqui. Neste momento, ainda como parte do debate conceitual que aponta favoravelmente para a opção pelo mural como dispositivo de acesso às interações na sala de professores, recorro à noção de compreensão responsiva ativa, de M. Bakhtin.

Para ele, todo ato de recepção de um enunciado é já uma resposta:

A compreensão de uma fala viva, de um enunciado vivo é sempre acompanhada de uma atitude responsiva ativa (conquanto o grau dessa atividade seja muito variável); toda compreensão é prenhe de resposta e, de uma forma ou de outra, forçosamente a produz: o ouvinte torna-se locutor. (BAKHTIN, 2000, p. 290).

A citação acima coloca em questão exatamente o tipo de observação que apresentei anteriormente: a compreensão não é mera extração de conteúdos fixados em um texto no momento de sua produção. A compreensão é uma atitude, pressupõe não o desvendamento, mas a participação em um diálogo, em que o coenunciador assume uma postura que ele chama de compreensão responsiva ativa. Assim, o interlocutor não é mera instância de recepção passiva de enunciados aos quais responderia somente após seu processamento. A compreensão possui uma antecipação de resposta. Ao concordar, discordar, completar, interromper, retirar-se, o coenunciador manifesta-se ativamente. Compreender é, assim, posicionar-se.

$\mathrm{Na}$ interação verbal, se o coenunciador não é mera instância de recepção, o enunciador também não pode ser considerado ponto original de uma determinada troca. Para dar conta deste aspecto, Bakhtin insistiu, afirmando que 
... o próprio locutor como tal é, em certo grau, um respondente, pois não é o primeiro locutor, que rompe pela primeira vez o eterno silêncio de um mundo mudo, e pressupõe não só a existência do sistema da língua que utiliza, mas também a existência dos enunciados anteriores - emanantes dele mesmo ou do outro - aos quais seu próprio enunciado está vinculado por algum tipo de relação [...] (BAKHTIN, 2000, p. 291).

Afixar textos no mural e os ler são atividades que se configuram a partir de certas regras, de uma dinâmica institucional que se instaura distribuindo lugares, convocando posicionamentos. Não só a afixação de um texto, mas também a sua leitura configuram-se como convites à participação em um diálogo, em que, quando se realiza, cada réplica, ainda que breve, fragmentária, pontual "possui um acabamento específico que expressa a posição do locutor, sendo possível responder, sendo possível tomar, com relação a essa réplica, uma posição responsiva" (BAKHTIN, 2000, p. 294).

Como afixar textos no mural, simultaneamente, produz e pressupõe um conjunto de pré-condições (o hábito de ler os textos do mural por parte dos profissionais, a expectativa de que tais textos sejam importantes profissional ou pessoalmente, necessidades de conhecimento relativo a certos temas, possibilidade de alguém "alimentar" o mural com textos, entre outros aspectos), considero tal atividade como a enunciação de certos saberes que se supõem necessários ao trabalho docente.

Assim, optar pelo mural como campo produtor de pistas para análise implica não somente a explicitação dos critérios adotados em relação ao tempo de observação e aos diferentes elementos linguísticos considerados na construção do córpus ${ }^{4}$. É necessário também compreender o lugar conferido ao mural no jogo complexo de interações ocorridas na sala dos professores. Um entrelaçamento se realiza entre esses textos de tal modo

\footnotetext{
${ }^{4}$ Utilizo a grafia córpus (sing. e pl.), considerando a frequência de seu uso no campo dos estudos linguísticos. Trata-se de forma (ainda) não dicionarizada em língua portuguesa, situação que difere da que se verifica em francês, língua em que se atesta $\mathrm{O}$ registro de formas como «le(s) corpus » já no século XIX (Lexis - dictionnaire de la langue française, Larousse).
} 
que passa a não fazer muito sentido, observando sua dinâmica cotidiana, opor os textos escritos às conversas, aos comentários, às reações mais vibrantes ou mais acomodadas. Dessa forma, considera-se que "os enunciados não são indiferentes uns aos outros nem são autossuficientes; conhecem-se uns aos outros, refletem-se mutuamente" (BAKHTIN, 2000, p. 316).

Ao fundamentar a escolha do mural como fonte da produção/ circulação de textos, aproximarei essa opção da ideia de "acesso a dada uma massa de textos" formulada por Rocha, Sant'Anna e Daher (2004) para tratar da entrevista em situação de pesquisa acadêmica. Meu objetivo com tal aproximação constitui-se em: i) sustentar a "coleta de textos" do mural como um dispositivo enunciativo; ii) dar visibilidade à intervenção do pesquisador em tal atividade.

Em relação ao primeiro objetivo, direi que, de um ponto de vista enunciativo, trabalhar com os textos do mural não se restringe a retirá-los do mural, providenciar cópias e afixá-los novamente, como supõe a atitude de coleta de dados. Há uma reflexão prévia acerca do lugar conferido a tal dispositivo de circulação de textos no conjunto das interações realizadas na sala dos professores. A própria existência de uma sala dos professores, em detrimento de uma sala dos funcionários, por exemplo, contribui para a compreensão do mural como dispositivo de circulação de textos que não pode ser ignorada.

O segundo objetivo é, portanto, desdobramento do anterior, na medida em que propõe que o conjunto de reflexões destacadas acima seja explicitado como intervenção do pesquisador. Trata-se de um esforço no sentido de afastar a ideia de que o pesquisador simplesmente "coleta" algo que o preceda. Neste contexto, a citação a seguir de Bakhtin soa como uma advertência aos analistas do discurso:

O ato humano é um texto potencial e não pode ser compreendido (na qualidade de ato humano distinto da ação física) fora do contexto dialógico de seu tempo (em que figura como réplica, posição de sentido, sistema de motivação). (BAKHTIN, 2000, p. 334).

A respeito da opção pela utilização da pesquisa como dispositivo de acesso a uma dada “massa de textos”, Rocha, Sant'Anna e Daher (2004) afirmam: 
Para abordar a entrevista no âmbito da pesquisa acadêmica, partimos da evidência de diferentes textos que circulam em espaços e suportes variados (impressos, conversas cotidianas, interações sistemáticas ou casuais, de mais fácil ou mais difícil acesso, etc.) e que se revelam, por extenso, indicadores da existência de diferentes comunidades discursivas. A referida evidência da existência desses textos é que nos possibilita ingressar em uma atividade de pesquisa: só se propõe, por exemplo, a realização de uma entrevista no curso de uma pesquisa quando se sabe que determinado(s) texto(s) existem(m) no universo de discursos produzidos. (ROCHA; SANT'ANNA; DAHER, 2004, p. 169).

Desse modo, ao se optar pelo mural como campo produtor de pistas para a análise estou pressupondo que haja uma "massa de textos", um conjunto de interações sendo produzido na sala de professores, dos quais o mural representa um possível recorte. A própria existência do mural já pressupõe uma escolha de alguns entre tantos outros textos, que circulam por outros momentos e em outros espaços, tendo como referência um propósito comunicativo de falar aos professores. Assim como a escolha de alguns entre tantos outros textos pressupõe certo funcionamento do mural, põe em ação seu propósito comunicativo, a seleção a que se procedeu desses textos não pode ser compreendida como uma simples "coleta", mas como uma "nova situação de enunciação" que viabilizará a construção de outros textos, de outra possibilidade de falar sobre o trabalho docente. Trata-se de inventar um caminho de acesso a esses textos, aproximar-se de saberes que circulam no cotidiano de trabalho do professor, em relação aos quais, mantendo-os na invisibilidade, se contribui para que sejam tidos como naturais, inquestionáveis, ou meramente informativos.

Retomo, uma vez mais, o paralelo entre a opção pelo mural e a reflexão acerca da entrevista em pesquisa acadêmica, com enfoque discursivo. Rejeitando a entrevista como "captura da verdade do entrevistado", os referidos autores consideram a entrevista como um dispositivo complexo, atribuindo-lhe três momentos:

- o momento da preparação da entrevista: momento em que, lançando mão dos saberes que possuímos acerca do outro e com base em objetivos determinados, produzimos uma espécie de 
'roteiro' condutor de algo que se poderia considerar uma 'interação antecipada' com o outro que se pretende entrevistar;

- momento da realização da entrevista: situação que estará assentada nas bases definidas por um roteiro, responsável por atualizar, sob o signo da interação entrevistador-entrevistado, textos já produzidos anteriormente em diferentes situações de enunciação;

- momento que se segue à entrevista: situação na qual o pesquisador estará em condições de finalmente decidir sobre um córpus sobre o qual trabalhará, a partir do conjunto de textos produzidos. (ROCHA; SANT'ANNA; DAHER, 2004, p. 177).

Por analogia aos três momentos definidos anteriormente, as etapas de coleta e seleção dos textos escolhidos para a análise se configuraram a partir de um processo de reflexões. A opção pelo mural é o primeiro desses momentos. No entanto, cabe esclarecer, à luz do que os referidos autores tratam a respeito da entrevista, a própria escolha do mural é motivada por alguns pressupostos. Minha tarefa é explicitá-los, conforme se viu anteriormente, e discutir sua relevância no que tange ao potencial de diálogo que estabelece com os objetivos da pesquisa em análise.

No presente caso, o momento de preparação para a seleção de textos do mural representa o conjunto de questionamentos elaborados acerca desse dispositivo aparentemente de "transmissão de informações". Essa problemática do suporte mobilizou a primeira etapa.

Em seguida, procedeu-se à coleta do material ao longo de oito meses de observação empírica. Essa coleta envolveu ainda um conjunto de anotações em "diário de bordo" acerca dos contextos de emergência de cada um desses textos.

\section{A Construção do Córpus de Análise}

No item anterior, ao apresentar a noção de compreensão responsiva ativa, procurei demonstrar o tipo de reflexão que ela traz para o campo dos estudos da linguagem, acentuando a relação entre texto e ato. Compreender um texto pressupõe antecipar-se em uma resposta potencial, assumir posicionamento.

Neste item, explicito os critérios de seleção de textos para compor o córpus da pesquisa em análise, articulando-os com a noção de gêneros do 
discurso. Opto por inicialmente apresentar a definição dada por Bakhtin e, em seguida, indico os elementos elaborados por Maingueneau para identificação dos gêneros, que me parecem mais adequados para problematizar os textos encontrados no mural. Na sequência dessa discussão conceitual inicial, exploro alguns confrontos entre os textos, ressaltando a impossibilidade analisá-los separadamente. Os sentidos produzidos pelo mural sobre a docência ganham consistência exatamente por convocarem o professor ao trabalho a partir de posicionamentos diversos e, em alguns casos, até divergentes.

A definição de gêneros do discurso dada por Bakhtin refere-se à elaboração de "tipos relativamente estáveis de enunciados" (BAKHTIN, 2000, p. 280). É essa estabilidade relativa da produção de enunciados associada às diferentes esferas da atividade humana que permite superar o ponto de vista segundo o qual a linguagem em uso seria heteróclita e, portanto, não se viabilizaria como objeto científico.

É necessário ressaltar que, para salientar a relativa estabilidade das realizações linguísticas, essas realizações devem estar indissociavelmente ligadas às diversas esferas da atividade humana. A respeito dessa observação, vejamos o que o próprio Bakhtin nos diz: "A utilização da língua efetua-se em forma de enunciados (orais ou escritos), concretos e únicos, que emanam dos integrantes duma ou doutra esfera da atividade humana" (BAKHTIN, 2000, p. 280).

O referido autor oferece ainda três elementos que, associados, comporiam o todo de um gênero do discurso. São eles o conteúdo temático, o estilo e a construção composicional. A ideia de que o todo do gênero é representado pela fusão desses três elementos, entre outros aspectos, distancia-se do uso que o formalismo russo fez do conceito de gêneros literários, os quais eram identificados como resultado, o último elemento da dissecação dos textos. Os gêneros literários seriam como o somatório de certas estruturas.

Para Bakhtin, uma vez que a comunicação verbal se dá por gêneros do discurso, esses tipos relativamente estáveis permitem que o interlocutor tenha uma posição ativa na interação. A compreensão do gênero a que pertencem os enunciados confere às produções de linguagem uma totalidade e é essa noção de acabamento do gênero que possibilita a troca na interação verbal. 
É necessário o acabamento para tornar possível uma reação ao enunciado. Não basta que o enunciado seja inteligível no nível da língua. Uma oração totalmente inteligível e acabada, se for uma oração e não um enunciado - constituído de uma única oração - não poderá suscitar uma reação de resposta: é inteligível, está certo, mas ainda não é um todo. (BAKHTIN, 2000, p. 299).

A articulação entre a ideia de indissociabilidade dos três aspectos que compõem o gênero (o conteúdo temático, o estilo e a construção composicional) e a de acabamento tem como desdobramento o modelo de interação verbal em que a relação entre os interlocutores não é de mão única, como supõe o esquema linear discutido nas Considerações iniciais deste artigo. Não são, portanto, mensagens que se transmitem, mas enunciados que se estabilizam em dado contexto sócio-histórico.

Dito isto, passo agora à proposta de critérios para definição de gêneros do discurso elaborada por Maingueneau (2001). Tal proposta é motivada por um largo uso da referida noção que apresenta insuficiências, em pontos de vista que consideram ou apenas tipologias enunciativas, ou somente tipologias comunicacionais/situacionais. De um lado, as tipologias enunciativas parecem não levar em conta a inscrição social da atividade enunciativa. Por outro, as tipologias comunicacionais/situacionais não consideram o funcionamento linguístico dos textos. Como proposta de superação das insuficiências apontadas em ambos os modelos, Maingueneau salienta que tipologias discursivas deveriam procurar articular um dado funcionamento linguístico com sua inscrição social.

A partir da noção de gêneros do discurso elaborada por Bakhtin, Maingueneau (2001) propõe cinco critérios para conceber um gênero. São eles: a) uma finalidade reconhecida; b) o estatuto de parceiros legítimos; c) o lugar e o momento legítimos; d) um suporte material; e) uma organização textual.

Ao considerar em sua proposta, tanto aspectos comunicacionais/ situacionais como os das letras "a", "b", "c" e “d”, quanto aspectos linguísticos como "e", Maingueneau expressa a preocupação de superar, conforme explicitado acima, modelos que optem somente por um ou outro aspecto da produção de linguagem. Com efeito, tal tipologia discursiva contribuiria para não apartar, de um lado, uma inscrição social dos textos, e, de outro, um dado funcionamento linguístico correspondente. Dessa forma, 
assegura-se um avanço em relação à definição elaborada por Bakhtin, na medida em que a integração dessas perspectivas saliente uma dinâmica institucional implicada nas práticas de linguagem. Tal dinâmica é desdobramento do que Maingueneau já havia apresentado anteriormente: "se quisermos tornar a emergência de uma obra pensável, sua relação com o mundo no qual ela surge, não é possível separá-la de seus modos de transmissão e de suas redes de comunicação" (MAINGUENEAU, 1995, p. 83).

A partir desses critérios, é possível notar que, quer tenham sido "retirados" de seu contexto habitual de circulação, quer tenham sido produzidos para figurar no mural, o suporte material dos gêneros atravessa a todos. Todos os gêneros, independente das diversas motivações, puderam ser afixados no mural. Ao observar este critério sendo articulado simultaneamente com os demais e não sendo tratado secundariamente, procurarei destacar de que modo esse aspecto se mostra, em dadas circunstâncias como estruturador de certos níveis de lutas constitutivas do mural. O fato, portanto, de um gênero ter sido, supostamente, retirado de seu contexto habitual de circulação promove um deslocamento não só do suporte material, mas reconfigura os embates entre os parceiros da comunicação, o tempo e o espaço da enunciação, etc..

Se se considerar o conjunto dos textos observados, encontrou-se um número bastante razoável - cerca de trinta e cinco, se estiverem incluídos nessa contagem também os que não compõem o córpus de análise. No entanto, se se levar em conta que o período de observações abrangeu oito meses, percebe-se a frequência de menos de cinco textos por mês. Surpreendeu ainda a permanência dos textos no mural por períodos prolongados. A maior parte dos textos afixados até o recesso do mês de julho permaneceu no mural durante todo o primeiro semestre.

Agora, cabe discutir a elaboração de critérios que permitam perceber quais dos textos que circularam pelo mural poderiam dialogar com as questões colocadas pela pesquisa em análise, de maneira que se pudesse refletir adequadamente acerca da produção/circulação de imagens discursivas do trabalho docente.

O conjunto de textos observados abrange uma diversidade considerável, tal como se pode notar na seguinte descrição: textos administrativos de circulação institucional - como o mapa de controle de frequência, comunicados oficiais, textos transcritos do Diário Oficial -, de 
circulação restrita à escola - como as circulares, os bilhetes -, textos publicitários - cartazes de divulgação de livros didáticos, anúncios de promoções de eletrodomésticos -, textos retirados de jornais - notícias que tematizam o trabalho dos profissionais de educação, gravidez na adolescência, casos recentes de corrupção de parlamentares, conhecidos como "mensalão" -, poema, textos políticos - que tratam da legislação trabalhista e da organização político-sindical dos profissionais.

Sabe-se que todos os textos que figuraram no mural no período de observações constituem material importante para compreender os diferentes modos de produção/circulação de saberes do trabalho docente, na sala de professores. Por exemplo, a presença de um artigo de jornal abordando o episódio da política nacional em que parlamentares e ministros vinculados ao governo federal são acusados de corrupção (episódio que ficou conhecido como "mensalão") fala-nos de um mural que pressupõe a existência de um leitor que se interessa (ou se deseja que assim o seja) por questões que, ao menos aparentemente, extrapolam seu cotidiano mais imediato. $\mathrm{O}$ referido texto evidencia uma dimensão importante do mural, não interpela seus leitores apenas como professores de uma determinada escola, mas também como cidadãos, membros de uma determinada categoria, etc..

Com efeito, um texto que tematiza o episódio conhecido como "mensalão" interessa, em consonância com os objetivos propostos por esta pesquisa, apenas indiretamente, na medida em que chama a atenção para um funcionamento do mural distinto daquele que se poderia esperar.

Diante de tal diversidade de material, compreendeu-se a necessidade de elaborar critérios que permitissem confrontar esse conjunto de textos. Desse modo, o primeiro critério elaborado considerou a temática trabalho, em geral, não se restringindo ao trabalho docente. A opção por não especificar de antemão o tema trabalho docente deve-se ao fato de que, em se tratando de uma escola pública, podem circular no mural leis ou resoluções que tratem não apenas do trabalho do professor, mas do funcionalismo público, em geral. Nesse caso, os professores constituem parte de um grupo mais geral.

Tal critério incluiu os seguintes gêneros do discurso: mapa de controle de frequência, notícia de jornal, cartaz publicitário, circular, nota informativa.

No mapa de controle de frequência, consta a lista de profissionais lotados na escola ordenados pelo número de matrícula, da mais antiga à mais recente. Em tal mapa, como seu próprio nome revela, registra-se a 
frequência de cada um dos profissionais, mensalmente. Considero que cada código atribuído à frequência dos profissionais representa uma enunciação que tem como finalidade falar sobre o trabalho dos professores, atestando sua frequência.

Já em relação ao gênero notícia de jornal, consideraram-se como parte do córpus de análise quatro textos que tratam dos seguintes temas: a mudança nas regras do Programa "Nova Escola" de gratificação dos profissionais de educação da rede pública, instituído pelo governo do estado em 1999; agressão aos profissionais de educação por parte da polícia militar do estado do Rio de Janeiro, durante manifestação ocorrida em frente ao Palácio Guanabara, sede do governo estadual; substituição dos tradicionais quadros de giz por quadros brancos, nas escolas da rede pública estadual; falta de verbas relativa ao aumento do funcionalismo público estadual. Seja tratando diretamente das condições do trabalho, através das questões relativas à remuneração (conforme as notícias sobre o Programa "Nova Escola" e sobre a suposta falta de verba para conferir aumento salarial ao funcionalismo público), ou de aspectos infraestruturais (conforme a notícia sobre a substituição dos quadros de giz por quadro brancos), seja falando sobre elas, indiretamente, noticiando as manifestações realizadas pelos servidores, a temática que atravessa todas essas notícias vincula-se ao trabalho dos profissionais de educação.

No gênero cartaz publicitário, consideraram-se pertinentes os textos de publicidades de livros didáticos, excluindo-se assim, por exemplo, propagandas de eletrodomésticos.

Quanto à circular e à nota informativa, ambos os textos remetem a prescrições para o trabalho, seja determinando datas de prova, de recuperação, de conselho de classe, seja estabelecendo processos relativos à licença prêmio e à movimentação de servidores.

O segundo critério elaborado para a definição dos textos que compõem o córpus de análise estabelece a necessidade de uma marca linguística que identifique os profissionais de educação, em geral, ou os professores, em particular, como interlocutores prioritários dos textos afixados no mural. A partir de tal critério estariam incluídos a resolução, o bilhete e o panfleto. Embora alguns bilhetes tematizem de modo mais explícito o trabalho docente, tal temática nem sempre se encontra em evidência no texto. Há um bilhete que simplesmente convoca alguns professores a comparecerem ao SOP (Serviço de Orientação Pedagógica). 
Diante desses dois critérios mais gerais, ainda assim houve textos importantes, que não estariam incluídos no córpus. Nesse sentido, considerou-se uma justificativa que não se pauta pela temática, ou mesmo por certas marcas linguísticas, mas que atentam para o funcionamento de tais textos com o intuito de incluí-los no córpus de análise.

Esses textos são os versículos bíblicos e o poema "O analfabeto político”, de B. Brecht. Sustenta-se que tais textos devem permanecer entre os que compõem o córpus de análise. Primeiro, em relação ao versículo bíblico, ele faz parte da ornamentação do mural. Esse é, portanto, o único texto que permaneceu ao longo de todo o ano. Além disso, implicitamente, trata de certa moral para o trabalho. Neste sentido, esse texto tematiza, mesmo que implicitamente, o trabalho, em geral. Estando ele no mural, fazendo parte de sua ornamentação, naquele contexto de circulação, constrói como seu interlocutor docente que se encontra na sala de professores.

Já o poema "O analfabeto político", apesar de não se dirigir explicitamente aos professores, nem tematizar o trabalho docente, é afixado no mural em um período em que a rede estadual estava promovendo paralisações periódicas. Havia, portanto, um debate aberto na escola acerca da adesão dos profissionais e sua participação em atividades de rua e assembleias. Nesse período, considerou-se que houve uma sequência, cronologicamente organizada, de três textos: o primeiro deles é o poema, seguido de dois panfletos, um que trata da inconstitucionalidade de aplicar o código 61 como punição aos grevistas e outro que pretende fazer uma avaliação das mobilizações ao longo do ano. É por figurar nessa sequência que se sustentou que esse texto devesse figurar no córpus de análise.

Por fim, faço uma indicação de análise que considero importante confirmação acerca da produtividade dos encaminhamentos metodológicos adotados. Embora não seja possível desdobrar, nos limites do presente artigo, o que vou apresentar, não posso me refutar de destacar ao leitor que a descrição acima já antecipa a produção de séries diversas de embate entre os textos. O leitor do mural, quando entra na sala de professores, depara simultaneamente com certo conjunto de textos afixados. Essa simultaneidade da experiência com o mural parece-me elemento suficiente para evidenciar que a leitura dele nunca se dá isoladamente, mas pela entrada em certo arranjo de textos.

Sem dúvida, o que destaco aqui é perfeitamente compatível com a seguinte observação de Maingueneau (2001, p. 85, grifos do autor): “um 
texto não é um conjunto de signos inertes, mas o rastro deixado por um discurso em que a fala é encenada". O quadro cênico envolve a cena englobante, que se refere ao tipo de discurso, e a cena genérica, que se delimita pelo gênero do discurso. Desse ponto de vista, um leitor do mural deve ser capaz de diferenciar um panfleto ou um cartaz publicitário, reconhecendo a que tipo de discurso remetem (ou seja, ao discurso político ou publicitário) e, por conseguinte, de que modo interpela seu leitor (como membro de uma categoria, ou como consumidor). Já a cena genérica confere papéis determinados aos participantes da enunciação. Define também uma finalidade, modos de circulação etc.

No entanto, adverte Maingueneau, "não é diretamente com o quadro cênico que se confronta o leitor, mas com uma cenografia" (MAINGUENEAU, 2001, p. 87). Com efeito, não me parece ser possível considerar que a cenografia instaurada se produza a partir de cada um dos textos isoladamente, mas de séries, de cruzamentos variados que o próprio leitor inaugura no momento da leitura. Ao serem afixados no mural, os textos passam a compartilhar de uma finalidade reconhecida, pressupondo para cada um dos participantes da interação papéis definidos.

\section{Considerações Finais}

No presente artigo, a ênfase conferida à discussão metodológica reivindica sua pertinência na própria trajetória de rupturas instauradas pelos estudos do discurso. Retomei o esquema linear de comunicação, observando o tipo de reflexão conceitual subjacente a ele e incompatível com a perspectiva discursiva adotada.

Tratada como demanda de pesquisa, a queixa recorrentemente observada no cotidiano dos profissionais de educação disparou uma ida a campo e um questionamento acerca do dispositivo a ser utilizado para acesso às imagens discursivas do trabalho docente. Ao propor uma sequência de encaminhamentos que pretendiam desnaturalizar um funcionamento cotidiano, chegou-se à alternativa de análise dos textos afixados no mural da sala de professores. Com efeito, a questão que parece atravessar toda a reflexão empreendida aqui é inspirada na impossibilidade de considerar os textos descolados das formas de circulação.

A partir das noções de compreensão responsiva ativa, procurei demonstrar que afixar textos no mural pode ser assumido como ato de enunciação, já 
que não é possível retirar um texto de seu meio de circulação habitual e transferi-lo a outro, sem que isso seja motivado pela hipótese de que alguém nesse novo contexto queira/precise ter conhecimento. Dessa forma, esperase um posicionamento daquele que lê o texto, reconhecendo sua importância ou não, reagindo a ele de diferentes modos. Na sala de professores observada, destacou-se interação entre os textos afixados e as conversas cotidianas.

Ao tratar o meio de circulação como um dos critérios de delimitação dos gêneros do discurso, Maingueneau oferece possibilidade de argumentação, demonstrando que o deslocamento do contexto produz sentido. O mural atualiza prescrições para o trabalho docente que não se explicitam, em diversos exemplos, como ordens ou solicitações diretas.

Foi possível perceber que textos tão distintos produzem níveis variados de embates, propiciando o questionamento da suposta autonomia do texto frente ao mural. Ao deslocar textos, altera-se o quadro de referências, o modo de consumo dos textos. Com efeito, tais alterações permitem entender que os textos não compõem unidades autônomas, mas enunciados que podem ser lidos de diferentes modos e a partir de diversos lugares.

\section{Referências}

BAKHTIN, M. Estética da criação verbal. Tradução a partir do francês por Maria Emantina Galvão. São Paulo: Martins Fontes, 2000.

BERGMILLER, K. H. 1999. Ensino fundamental: mobiliário escolar. Brasília: FUNDESCOLA; MEC. Série Cadernos Técnicos I, n. 3. Disponível em: <http://www.fnde.gov.br/home/fundescola/ cadernos_tecnicos/instalacoes_escolares_nr3.pdf $>$. Acesso em: 3 ago. 2006.

CERTAU, Michel de. A invenção do cotidiano: artes de fazer. Tradução de Ephraim Ferreira Alves. Petrópolis: Vozes, 2003.

DEUSDARÁ, B. Imagens da alteridade no trabalho docente: enunciação e produção de subjetividade. 2006. Dissertação (Mestrado em Linguística) - Universidade do Estado do Rio de Janeiro, Rio de Janeiro. 
MAINGUENEAU, D. O contexto da obra literária: enunciação, escritor, sociedade. Tradução de Marina Appenzeller. São Paulo: Martins Fontes: 1995.

MAINGUENEAU, D. Novas tendências em análise do discurso. Tradução de Freda Indursky. Campinas: Pontes; Editora da Unicamp, 1997.

MAINGUENEAU, D. Análise de textos de comunicação. Tradução de Cecília P. de Souza-e-Silva, Décio Rocha. São Paulo: Cortez, 2001.

POSSENTI, S. Teoria do discurso: um caso de múltiplas rupturas. In: MUSSALIM, F.; BENTES, A. C. Introdução à Lingüistica: fundamentos epistemológicos. v. 3. São Paulo: Cortez, 2004. p. 353-392.

ROCHA, D.; DEUSDARÁ, B. Análise de Conteúdo e Análise do Discurso: aproximações e afastamentos na (re)construção de uma trajetória. Alea, Rio de Janeiro, v. 7, n. 2, p. 305-322, dez. 2005.

ROCHA, D.; DEUSDARÁ, B. Análise de conteúdo e análise do discurso: o lingüístico e seu entorno. DELTA, v. 22, p. 29-52, 2006.

ROCHA, D.; SANT'ANNA, V. L. A.; DAHER, M. C. F. G. A entrevista em situação de pesquisa acadêmica: reflexões numa perspectiva discursiva. Polifonia, Cuiabá, v. 8, p. 161-180, 2004.

Recebido em abril de 2013 Aprovado em agosto de 2013 